\title{
Notes on Prostigmata of Argentina 1: A new species of the genus Cryptognathus Kramer (Acari: Cryptognathidae)
}

\author{
Andrés O. PORTA \\ División Aracnología, Museo Argentino de Ciencias Naturales "Bernardino Rivadavia”, Av. Ángel Gallardo 470 \\ C1405DJR, Buenos Aires, Argentina. E-mail: hugporta@yahoo.com.ar
}

\begin{abstract}
Cryptognathus amalfitanii sp. nov. is described and illustrated based on samples collected from epiphytes of the species Tillandsia aëranthos (Bromeliaceae) from different trees in Buenos Aires, Argentina.

Key words: Epiphytes, Mites, Prostigmata.

Resumen: Notas sobre Prostigmata de Argentina 1: Una nueva especie del género Cryptognathus Kramer (Acari:Cryptognathidae). Se describe e ilustra Cryptognathus amalfitanii sp. nov. en base a muestras colectadas en epífitas de la especie Tillandsia aëranthos (Bromeliaceae) en varias especies de árboles en Buenos Aires, Argentina.
\end{abstract}

Palabras clave: Epífitas, Ácaros, Prostigmata.

\section{INTRODUCTION}

The family Cryptognathidae Oudemans, 1902 comprises 60 species in three genera (Dŏgan, 2008): Favognathus Luxton, 1973 (36 species), Cryptognathus Kramer, 1873 (22 species) and Cryptofavognathus Dŏgan and Dönel, 2010 (2 species) (Fan \& Zhang, 2005; Khanjani \& Ueckermann, 2008; Dŏgan 2008; Dönel \& Dŏgan, 2011; Uluçay \& Koç, 2013). Members of this family are recognized by the presence of a protective hood anterior of the propodosoma, and extremely extendable gnathosomal base in adults (Dŏgan, 2008). Three species of this family, all belonging to the genus Favognathus, have been described from South America (Dŏgan, 2008): F. agapictus (Flechtmann, 1971) from Brazil, $F$. ochraceus (Summers and Chaudhri, 1965) and $F$. pictus (Summers and Chaudhri, 1965) both from Galapagos Islands, Ecuador. In this work we describe the first species of the family from Argentina which also constitutes the first record of the genus Cryptognathus in the Neotropical region.

\section{MATERIALS AND METHODS}

Specimens were hand collected from epiphytes of the species Tillandsia aëranthos (Bromeliaceae) on different trees in the campus of the sport club Vélez Sarsfield (Fig. 1), Ciudad
Autónoma de Buenos Aires, Argentina and fixed in 96\% ETOH. Mites for optical microscopy were cleared in Nesbitt's fluid and mounted in Hoyer's medium following Walter \& Krantz (2009). Specimens were studied and measured under an Olympus BH-2 or a Leica D2500 compound microscope. Drawings were made with a camera lucida mounted on the microscope. For scanning electron microscopy (SEM), specimens were dehydrated through a series of ethanol solutions of increasing concentration in absolute hexamethyldisilazane (Porta \& Tricarico 2018) and then air-dried, mounted on individual stubs using adhesive copper tape, sputter-coated with gold-palladium and examined under a FEI XL 30 TMP scanning electron microscope varying the working distance and the voltage $(15-22 \mathrm{eV})$. SEM photographs were taken in two sessions in August 2017.

The terminology of palp and leg chaetotaxy follows that of Grandjean (1944, 1946) except for the adoption of the interpretation of Robaux (1975) for the $\boldsymbol{\kappa}$ setae of the genu I as one $\sigma$ solenidion. Idiosomal chaetotaxy terminology follows Kethley (1990) and Fan \& Zhang (2005). All measurements are given in micrometers $(\mu \mathrm{m})$ for the holotype and paratypes (in parentheses). The material examined is deposited at the Arachnological Collection of the Museo Argentino de Ciencias Naturales "Bernardino Rivadavia", Buenos Aires (MACN-Ar). 


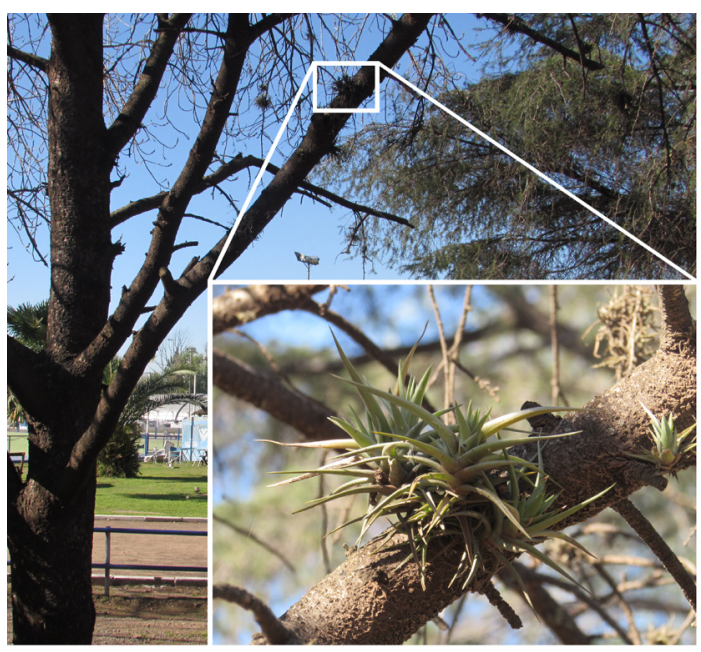

Fig. 1. Collecting locality with detail of the epiphyte Tillandsia aëranthos (Bromeliaceae) where the specimens Cryptognathus amalfitanii sp. nov. have been collected.

\section{RESULTS}

Family: Cryptognathidae Oudemans, 1902 Genus: Cryptognathus Kramer, 1879

Type species: Cryptognathus lagena Kramer, 1879

\section{Cryptognathus amalfitanii sp. nov.} (Figs. 2-12)

Etymology. The specific name is a patronymic in memory of José Luis "Don Pepe" Amalfitani (1894-1969) for his invaluable contribution to the developing of Club Atlético Vélez Sarsfield as a great social and sportive institution.

\section{Diagnosis}

Palptibial claw present (Figs. 8A-B, 9B), front margin of the hood smooth (Fig. 4A), dorsal shield entirely reticulated (Fig. 3) with irregular polygons, each with more than 10 pores uniformly distributed (Fig. 4B); ventral shield (Fig. 6) without reticulations, with an U shaped sector of pores behind setae $3 \boldsymbol{a}$ which extends laterally behind coxae IV and reaches ag1 but not the anterior ring of genital valves and with lateral patches of pores between coxae III and IV, behind coxae I, II and hypostosomal ring; with a central ventral region between setae $4 \boldsymbol{a}$ and $\boldsymbol{a g} 1$ with longitudinal striae (Fig. 7C) that becomes transversally oriented (Fig. 7B) before the genital plates (Fig. 3); solenidia $\omega$ of tarsi III and IV absent in females and present in males; tarsi III and IV with only one proximoventral seta (Figs.

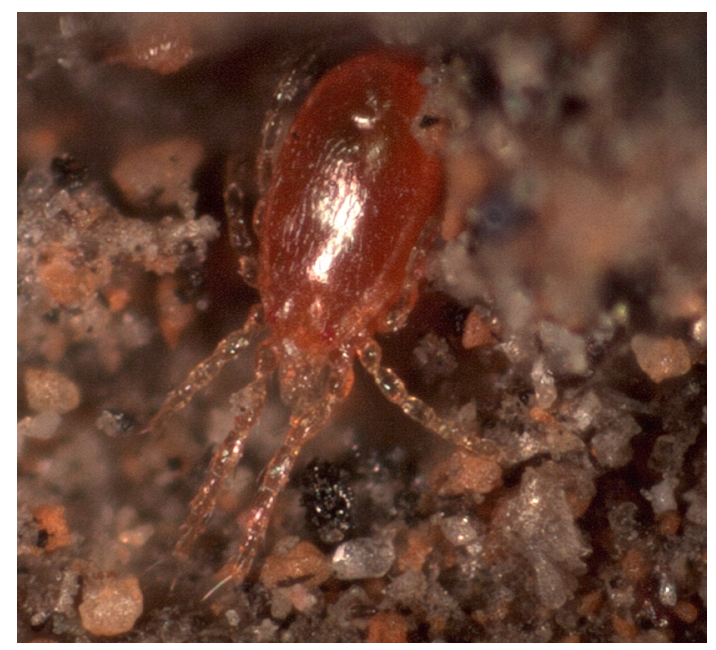

Fig. 2. Cryptognathus amalfitanii sp. nov. habitus alive.

10C-D, 12C-D), solenidion present on tibia III (Figs. 10C, 12C, E ) and absent on tibia IV (Fig. 10D); (tc) setae on tarsus II dissimilar, $\boldsymbol{t c}$ ' eupathidical and $\boldsymbol{t} \boldsymbol{c} "$ not (Fig. 12B).

\section{Comparisons}

According to the key for the genus by Uluçay \& Koç 2013, C. amalfitanii n. sp. resembles $C$. striatus Luxton, 1973 and C. vulgaris Luxton, 1973 by the reticulated dorsal shield, ventral shield without reticulations and front margin of hood smooth. It differs from C. striatus by the presence of both pores behind coxae IV and reticulation covering entire dorsal shield. From $C$. vulgaris by the absence of solenidia on female tarsus III and IV and by the presence of punctuation covering all dorsal shield.

\section{Type material}

Holotype, female (MACN-Ar 40686), hand collected from epiphytes of the species Tillandsia aëranthos (Bromeliaceae) on various trees, both exotic (Pinus sp., Populus sp.), and native (Schinus molle), in the campus of the sport club Vélez Sarsfield in Ciudad Autónoma de Buenos Aires $\left(34^{\circ} 38.023^{\prime} \mathrm{S}, 58^{\circ} 30.963^{\prime} \mathrm{O}\right.$ and altitude 10 m a.s.l), 16.VII.2017, A. O. Porta leg. Paratypes, same data, 6 females (MACN-Ar 40652, MACNAr 40670, MACN-Ar 40663, MACN-Ar 40644, MACN-Ar 40689, MACN-Ar 40666), 3 males (MACN-Ar 40649, MACN-Ar 40656, MACN-Ar 40691, MACN-Ar 40665), 2 inmatures (MACNAr 40645, MACN-Ar 40669) all mounted in slides and 2 females (MACN-Ar 40666, MACN-Ar 40640) mounted for MEB.

\section{Description}

Colour chilli red in live (Fig. 2). 


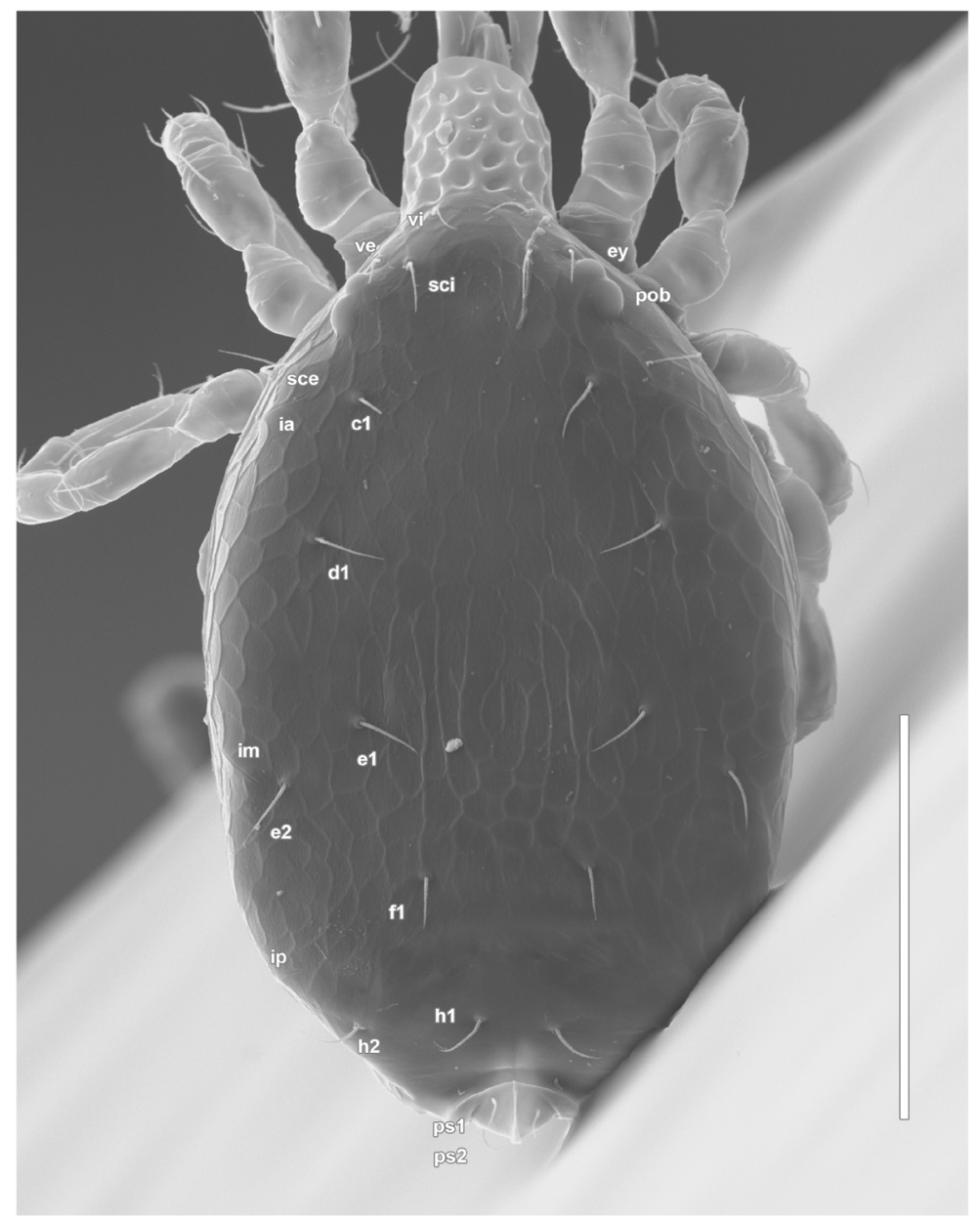

Fig. 3. Cryptognathus amalfitanii sp. nov., paratype (MACN-Ar 40666). Habitus dorsal. Scale bar: $100 \mu \mathrm{m}$.

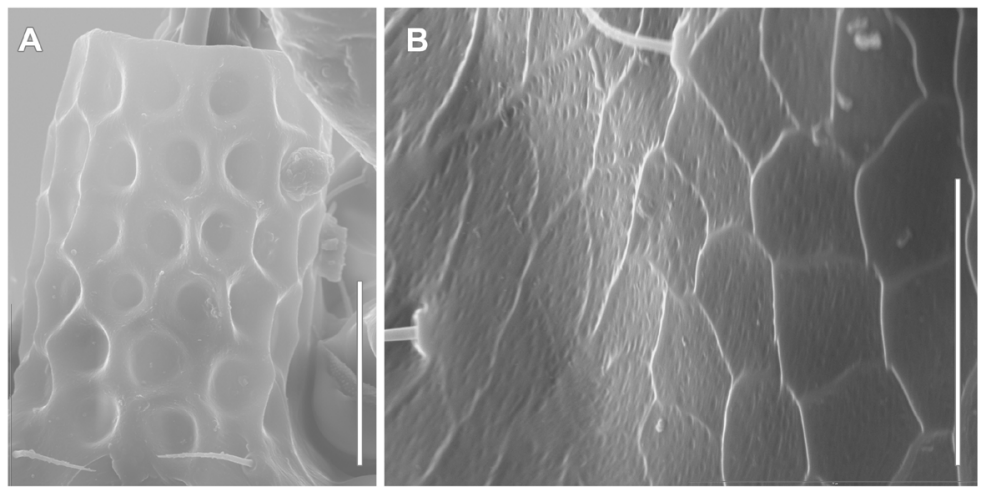

Fig. 4. Cryptognathus amalfitanii sp. nov., paratype (MACN-Ar 40666). A dorsal view of the hood; B. detail of the dorsal sculpture. Scale bars: A $20 \mu \mathrm{m} ;$ B $10 \mu \mathrm{m}$.

Female $(\mathrm{n}=7)$

Gnathosoma (Figs. 8 A-B, D, 9)

Chelicerae slender (Fig. 8D) 100 (98-108); mov- able digits 28 (24-28). Peritremes (pe.) ramifying just back digits articulation. Palp segments trochanter glabrous; femur with 3 setae (Fig. 8A, 


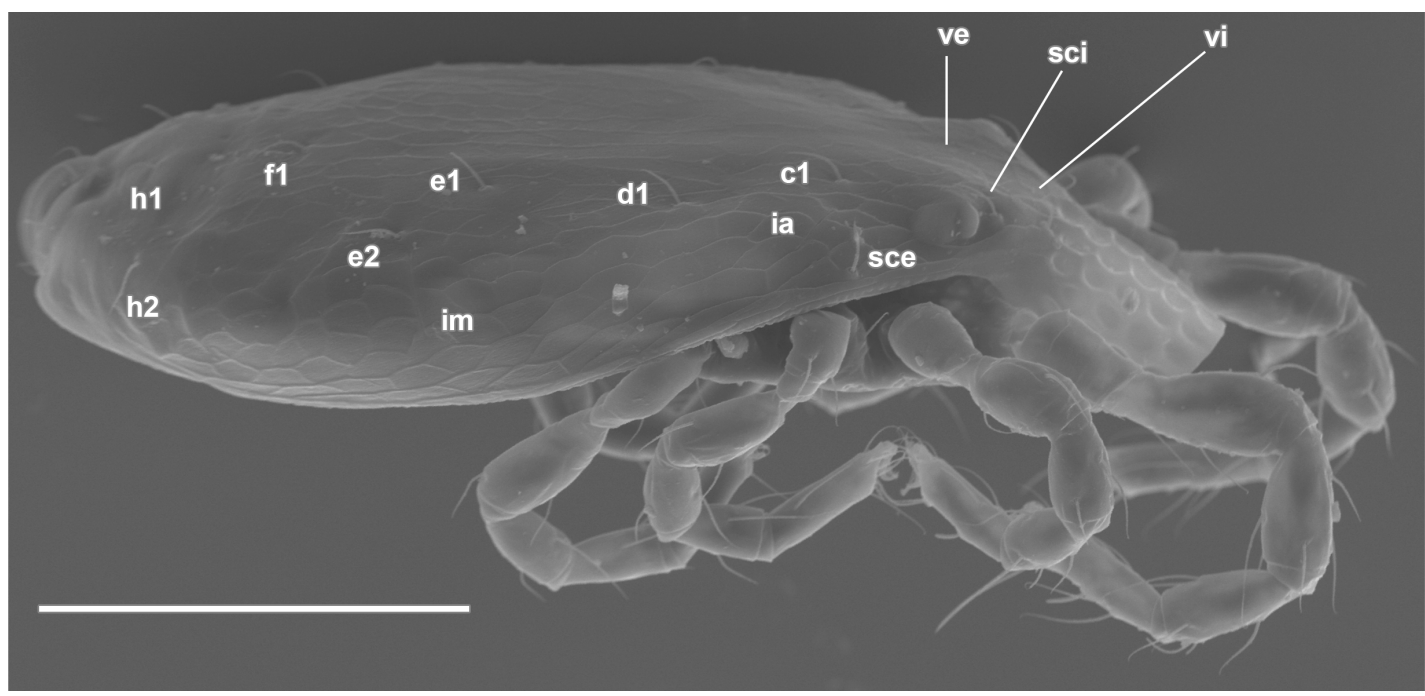

Fig. 5. Cryptognathus amalfitanii sp. nov., paratype (MACN-Ar 40640). Habitus in antiaxial view. Scale bar: $100 \mu \mathrm{m}$.

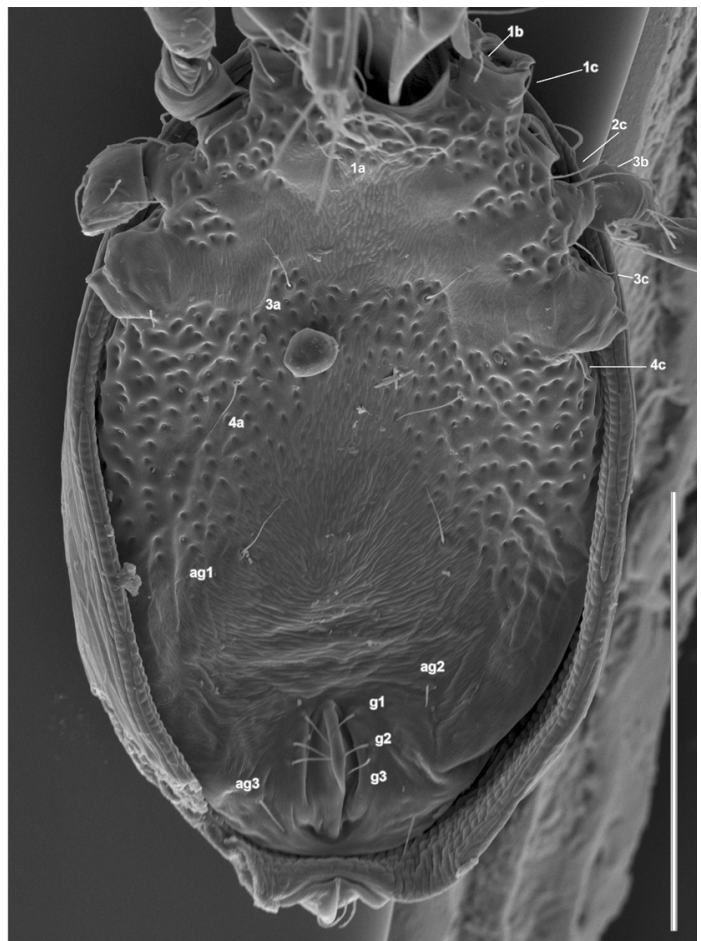

Fig. 6. Cryptognathus amalfitanii sp. nov., paratype (MACN-Ar 40640). Ventral view. Scale bar: $100 \mu \mathrm{m}$.

B), 36 (30-38) long; genu with 2 setae, 30 (26-30) long; tibia with 3 setae, 16 (14-18) long, palptibial claw present (Figs. 8A, B, 9B); tarsus 8 (8-10), with 7 setae and one solenidion, $(\boldsymbol{u l}), \boldsymbol{a c m}$ and sul eupathidical (Fig. 9C). Subcapitular setae $\boldsymbol{m}$ 26 (25-31), m-m 16; or1 10 or2 10.

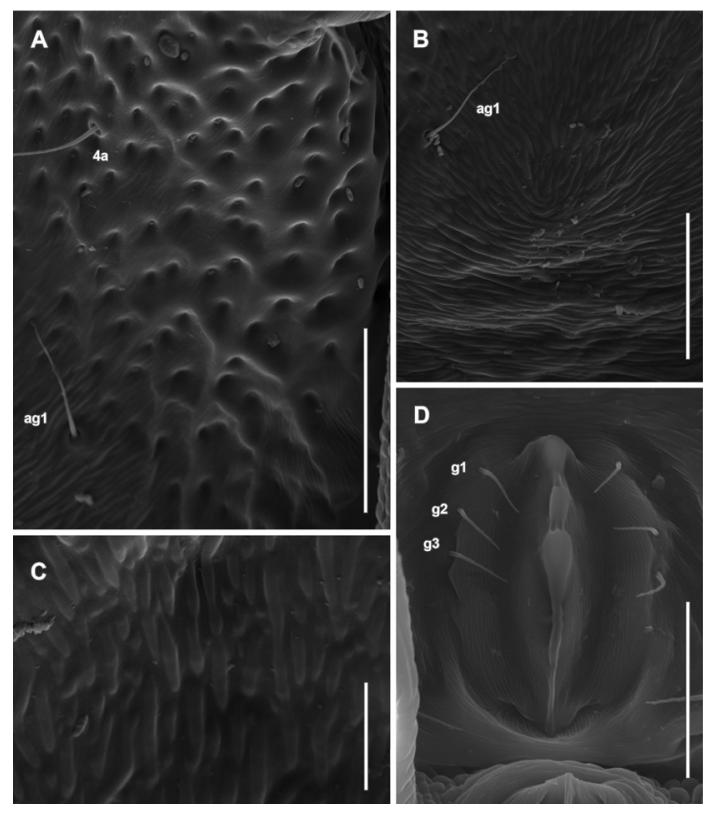

Fig. 7. Cryptognathus amalfitanii sp. nov., paratype (MACN-Ar 40640). Ventral view, A. Detail of the porous sector posterior to coxae IV; B. central striated sector anterior to genital valves; $\mathbf{C}$. detail of the same; D. genital valves. Scale bars: A; B; D $20 \mu \mathrm{m}$; C $5 \mu \mathrm{m}$.

Idiosoma (Figs. 2, 3) Oval in shape, 315 (245315) long, 162 (153-186) wide al level of coxae IV. Anterior margin of the hood smooth (Fig. 4A) with 5-6 dimples in each longitudinal row. Dorsal shield (Fig. 3) completely ornamented with reticulations except region beside setae $\boldsymbol{h} \mathbf{1}$, reticular 

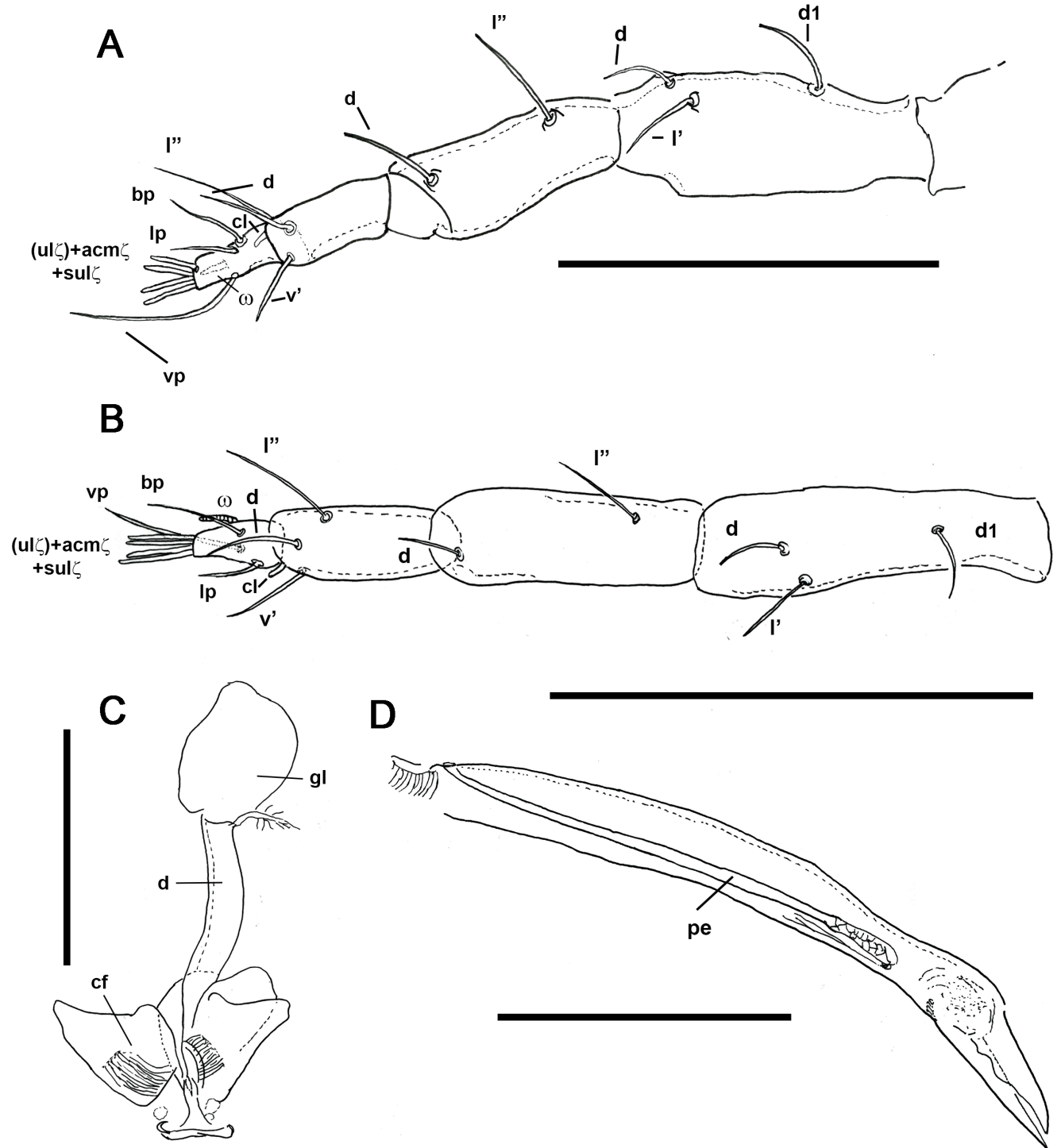

D

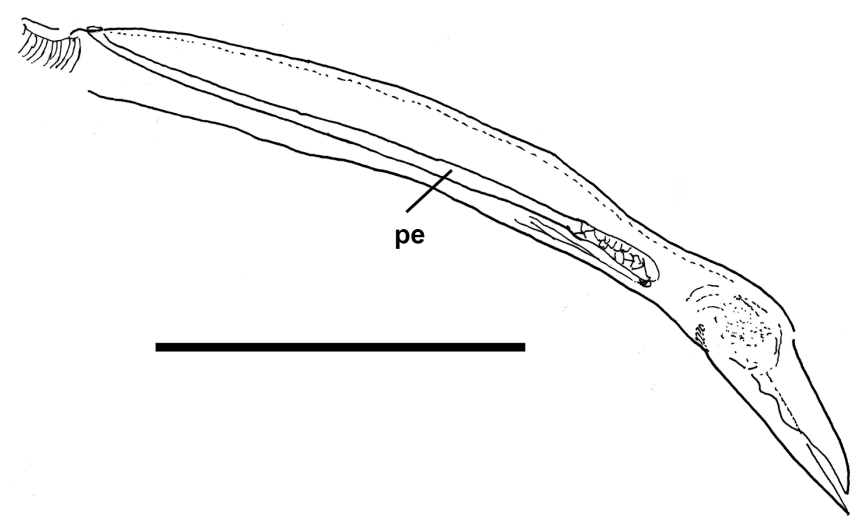

Fig. 8. Cryptognathus amalfitanii sp. nov., paratype (MACN-Ar 40689). A paraxial view of the palp; paratype (MACN-Ar 40663), B. dorsal view of the palp; paratype (MACN-Ar 40665), C. ventral view of the male genitalia; D. chelicera, antiaxial view. Abbreviations: cf: cuticular frame, cl: tibial claw, d: duct, gl: genital gland, pe: peritreme. Scale bars: A-D: $50 \mu \mathrm{m}$.

cells with more than 10 pores (Fig. 4B), pores distributed evenly in all reticulation cells; one pair of eyes and one pair of postocular bodies (pob) laterally between setae sci and sce. Eyes 6.4 (5-10) in diameter; pob 8.8 (8-11.2) in diameter. Dorsal shield with three pairs of slit-like cupules as follows: $\boldsymbol{i a}$ posterior to $\boldsymbol{c 1}$ (Figs. 3, 5), im posterior to setae $\boldsymbol{e} 1$ and anterior to $\boldsymbol{e} 2$ (Figs. 3, 5) and $\boldsymbol{i p}$ posterior to $\boldsymbol{f} \mathbf{1}$ and anterior to $\boldsymbol{h} \mathbf{1}$ (Fig. 3); polygonal cells (Fig. 4B) mostly longer than wide. Dorsal idiosomal setae smooth. Length of dorsal setae: vi: 12 (8-13); ve: 12 (7-13); sci: 12 (10-12); c1: 16 (11-17); sce: 15 (15-18); d1: 17 (13-17); e1: 16 (15-16); e2: 16 (13-18); f1: 12 (12-13); h1: 12 (10-13); h2: 15 (12-16). Distance between dorsal setae: vi-vi: 24 (24-30); vi-ve: 14 (10-19); ve-ve: 30 (26-30); ve-sci: 6 (4-10); sci-sci: 46 (28-46); c1-c1: 52 (45-53); sce-sce: 84 (80-102); c1-sce: 28 (30-32); d1-d1: 84 (64-84); d1-e1: 47 (45- 48); e1e1: 70 (68-76); e1-e2: 26 (21-27); e2-e2: 100 (102106); e1-f1: 48 (45-52); f1-f1: 48 (39-44); f1-h1: 36 (34-42); h1-h1: 20 (20-26); h1-h2: 27 (22-32); 


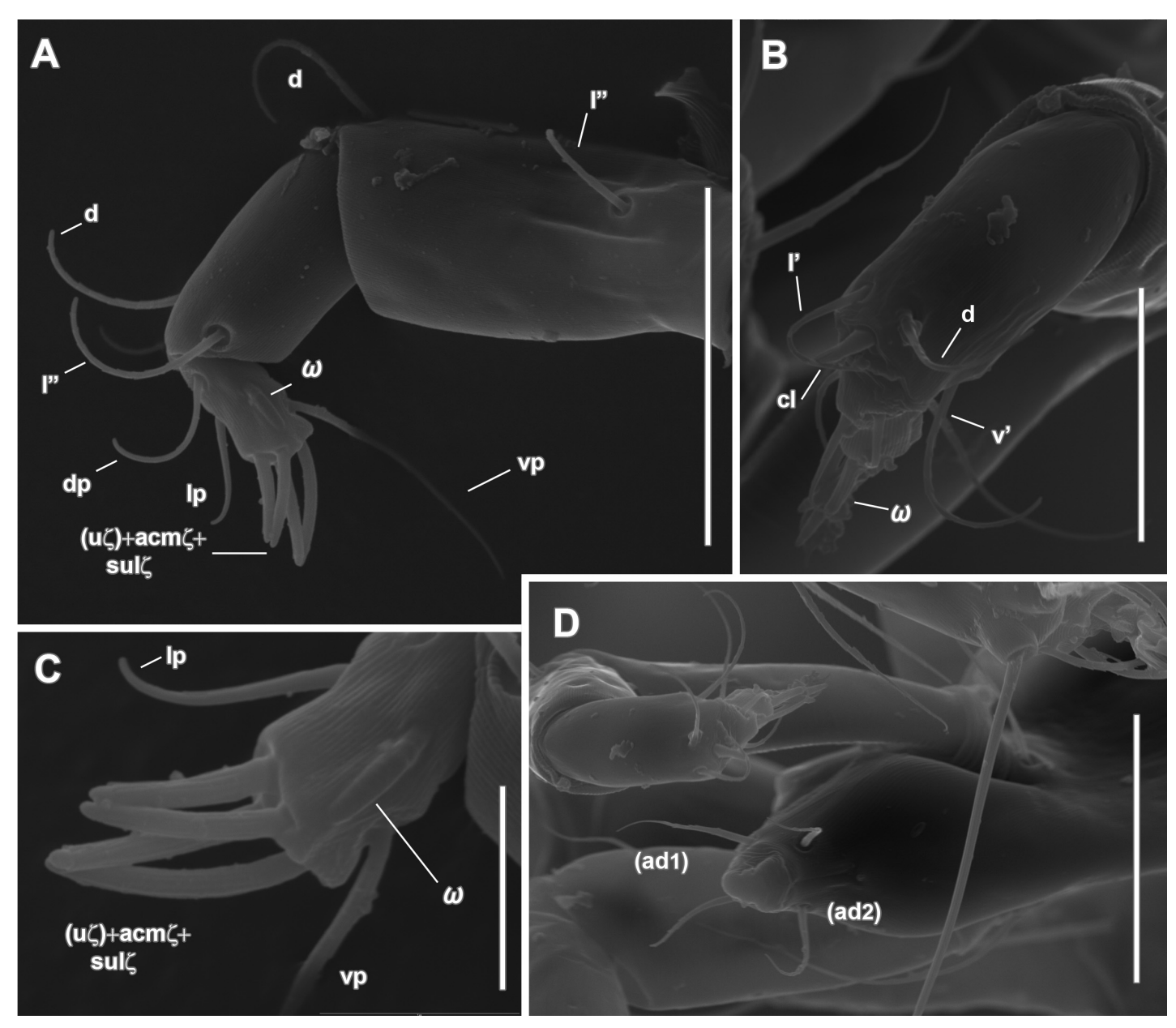

Fig. 9. Cryptognathus amalfitanii sp. nov. paratype (MACN-Ar 40666). A. antiaxial view of the left palp; paratype (MACN-Ar 40640), B. dorsal view of the left palp tibia; C. detail of the distal portion of the tarsus of the left palp; paratype (MACN-Ar 40666), D: hypostome. Scale bars: A; D $20 \mu \mathrm{m} ; \mathbf{B} 10 \mu \mathrm{m}$; C $5 \mu \mathrm{m}$.

\section{h2-h2: 78 (72-82).}

Ventral shield (Fig. 6), without reticulations, with an U shaped sector of pores behind setae $\boldsymbol{3 a}$ which extends laterally behind coxae IV and reaches $\boldsymbol{a g} \mathbf{1}$ but not the anterior ring of genital valves, and with lateral patches of pores between coxae III and IV, behind coxae I, II and hypostosomal ring; with a central ventral region between setae $\mathbf{4 a}$ and $\boldsymbol{a g} \mathbf{1}$ with longitudinal striae (Fig. 7C) that become transversally oriented (Fig. 7B) before the genital plates (Fig. 3). Ventral setae subequal, 1a:17 (20-24); 3a:14 (11-18); 4a: (1417); 1a-1a:18 (17-20); 3a-3a: 37(33-39); 4a-4a: 60 (56-68). Aggenital setae ag1: 12 (11-17); ag2: 12 (8-12); ag3: 9 (8-9); ag1-ag1: 48 (44-49); ag2-ag2: 53 (52-54); ag3-ag3: (36-40). Genital setae g1:12 (8-12); g2:10 (7-12); g3:10 (8-13). Pseudoanal setae ps1:10 (6-12), ps2:10 (9-10), ps3:11 (8-10).

Legs (Figs. 10, 11, 12) For measurements see table 1. Segments of legs with striae. Solenidion $\omega$ absent on tarsi III and IV (Figs. 10C, D, 12D, C); $\phi$ on tibiae IV absent (10D); I $\phi$ " at same level as $\boldsymbol{I} \boldsymbol{\phi}^{\prime}$ (Figs. 10A, 11D-E), more than $2 \mathrm{x}$ longer than $\phi^{\prime} ; \boldsymbol{I I} \phi$ on basal half of tibia II (Figs. 10B, $12 \mathrm{~A}) ; \boldsymbol{I I I} \phi$ on basal half of tibia III (Figs. 10C, $12 \mathrm{C}, \mathrm{E})$. Counts of setae and solenidia on legs I-IV: coxae (excluding 1a, 3a, and 4a) $2+1$ elcp, $1,2,1$; trochanters $1,1,2,1$; femora $3,3,2,2$; genua $5+1 \sigma, 4+1 \sigma, 2,3$; tibiae $5+2 \phi, 5+1 \phi$, $3+1 \phi, 3 ;$ tarsi $15+1 \omega, 12+1 \omega, 9,9$. Lengths of solenidia: I $\boldsymbol{\sigma}$ : 3 (3-4), II $\boldsymbol{\sigma}: 4$ (3-4), I $\boldsymbol{\phi}$ ': 5 (4-6), $\boldsymbol{I} \phi$ ": 12 (11-12), II $\phi: 6$ (6), III $\phi$ : 6 (6-7), I $\boldsymbol{\omega}$ : 10 (1012), II $\boldsymbol{~}: 7$ (6-8)

Male $(n=3)$

Similar to female but with enlarged solenidia 


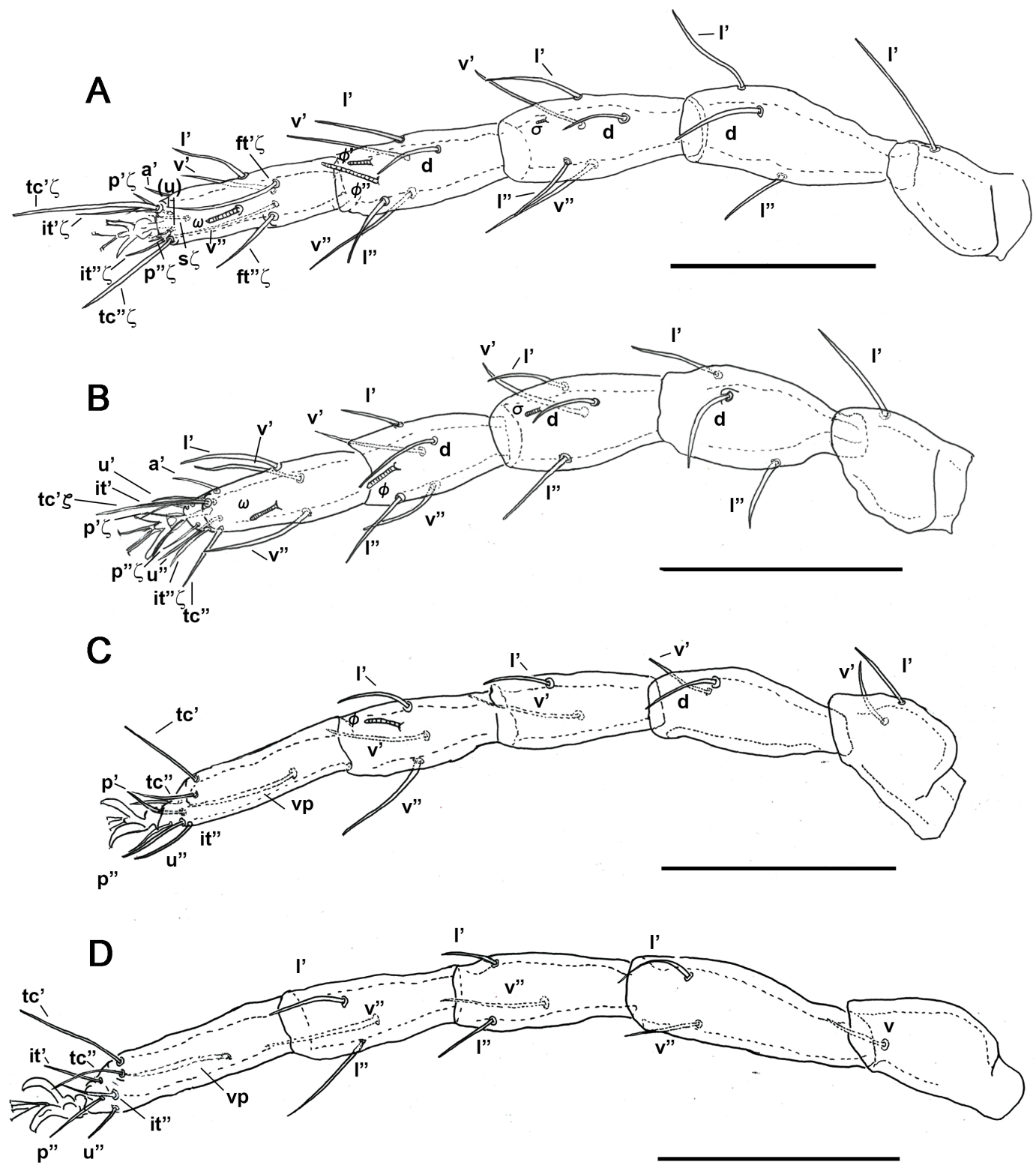

Fig. 10. Cryptognathus amalfitanii sp. nov. A-D, holotype (MACN-Ar 40686). Dorsal view of the left legs I-IV. Scale bars: A-D $50 \mu \mathrm{m}$.

Table 1: length of the leg segments of the female. Abbreviations: Tr.: trochanter, Fe.: femur, Ge.: genu, Ti.: tibia, Ta.: tarsus.

\begin{tabular}{cccccc}
\hline Leg|segment & Tr. & Fe. & Ge. & Ti. & Ta. \\
\hline I & $30(28-34)$ & $52(48-50)$ & $40(38-42)$ & $36(36-40)$ & $42(40-44)$ \\
II & $30(22-32)$ & $38(30-38)$ & $30(26-30)$ & $28(26-30)$ & $36(30-36)$ \\
III & $32(24-32)$ & $32(30-36)$ & $32(26-32)$ & $30(28-30)$ & $40(36-42)$ \\
IV & $30(30-40)$ & $44(40-46)$ & $34(32-38)$ & $34(30-36)$ & $40(36-42)$ \\
\hline
\end{tabular}




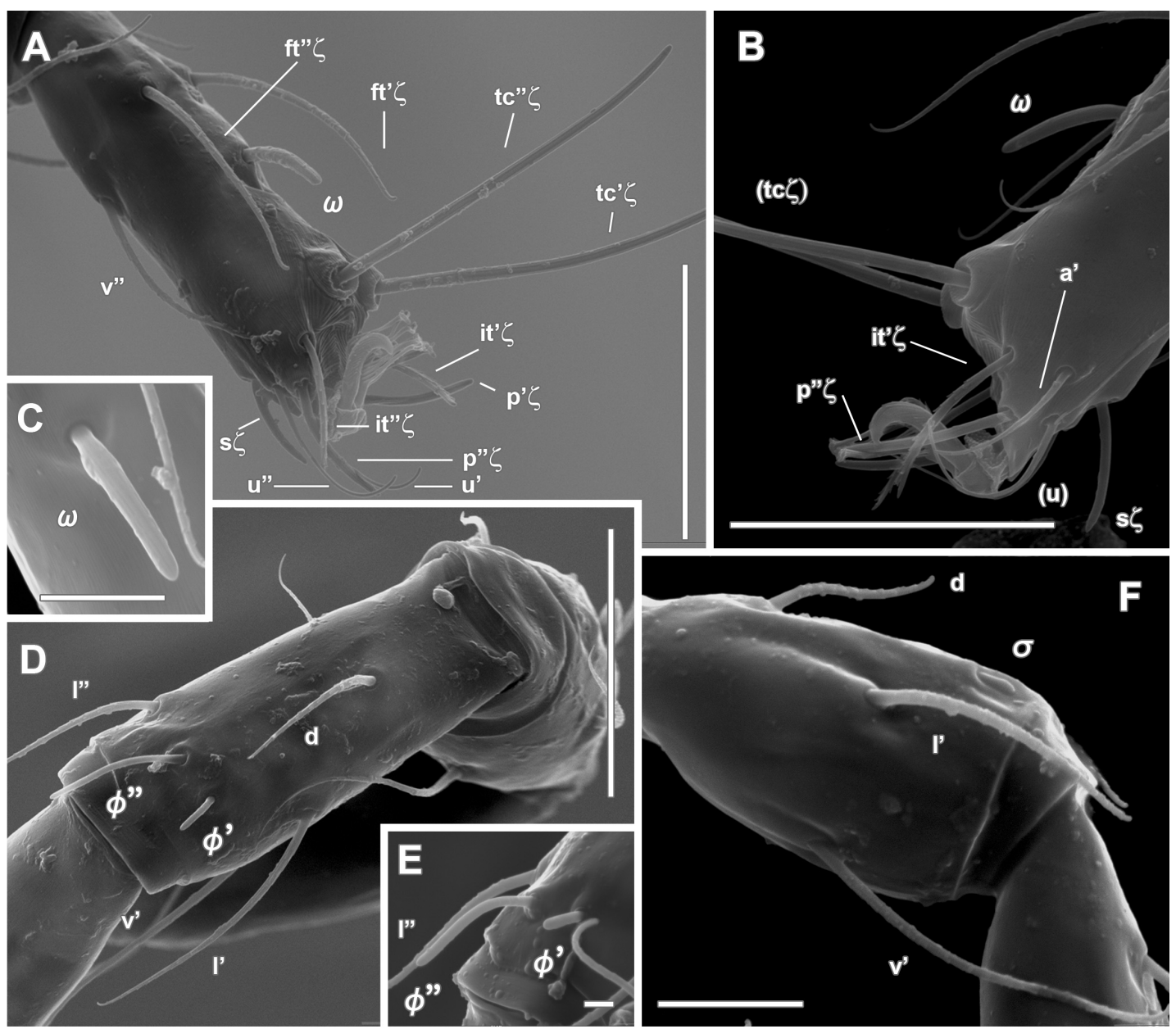

Fig. 11. Cryptognathus amalfitanii sp. nov., paratype (MACN-Ar 40666). Leg I: A. antiaxial view of the right tarsus; B. paraxial view of the right tarsus; C. detail of the tarsus solenidium; D. right tibia I, dorsal view; E same, detail of the solenidia; F paraxial view of the left genu. Scale bars: A; B; D $20 \mu \mathrm{m} ; \mathbf{C} 5 \mu \mathrm{m} ; \mathbf{E} 2 \mu \mathrm{m} ; \mathbf{F} 10 \mu \mathrm{m}$.

$\omega$ present in all legs and with genital and anal openings fused.

\section{Gnathosoma}

Chelicerae 80; movable digits 24-24. Palpal setae as in female; femur 28-34 long; genu 22-24 long; tibia 12-14 long, palptibial claw present; tarsus 8. Subcapitular setae $\boldsymbol{m}: 22-36, \boldsymbol{m}-\boldsymbol{m}$ : $6-12$, or 1 : 8, or2: 8.

\section{Idiosoma}

Oval, 224-240 long, 120-144 wide al level of coxae IV, hook 44-48 long with 4-5 dimples in each longitudinal row. Dorsal and ventral shields similar to female, but with setae $\boldsymbol{h} \mathbf{2}$ more advanced and more proximal to $\boldsymbol{f} \mathbf{1}$ than to $\boldsymbol{h} \mathbf{1}$; genital and anal openings fused and genital setae absent. Internal genitalia (Fig. 8C) with a cuticular frame $(\boldsymbol{c} f)$ connected by a long duct $(\boldsymbol{d})$ with a large impair gland $(\boldsymbol{g l})$. Eyes 4.8-6.4 in diameter; pob 8.8-16 in diameter. Length of dorsal setae: vi: $8-10$; ve: $8-12$; sci: $8-10 ;$ c1: 12-13.6; sce: $12-$ 14; d1: 16; e1: 10-16; e2: 12-14; f1: 9-10; h1: 1011; h2:10. Distance between dorsal setae: vi-vi: 21-24; vi-ve: $12-13$; ve-ve: 24 ; ve-sci: $4-6$; sci-sci: 36; c1-c1: 39-45; sce-sce: $80 ;$ c1-sce: $20-24$; d1d1: 64-66; d1-e1: 40-42; e1-e1: 46-48; e1-e2: 1822; e2-e2: 76-80; e1-f1: 35-38; f1-f1:24; f1-h1: 13-14; h1-h1: 14-17; f1-h2: 9; h1-h2:12; h2h2:16. Ventral setae, 1a: 12-16; 3a:15-18; $4 \boldsymbol{a}$ : 12-14; 1a-1a:14-15; 3a-3a: 30-32; 4a-4a: 44-48. Aggenital setae ag1: 10-12; ag2: 12; ag1-ag1: 42-44; ag2-ag2: 20. Pseudoanal setae ps1: 9-10; ps2: 8; ps3: 7.

Legs For measurements see table 2. Counts of setae and solenidia on legs I-IV as in female, 

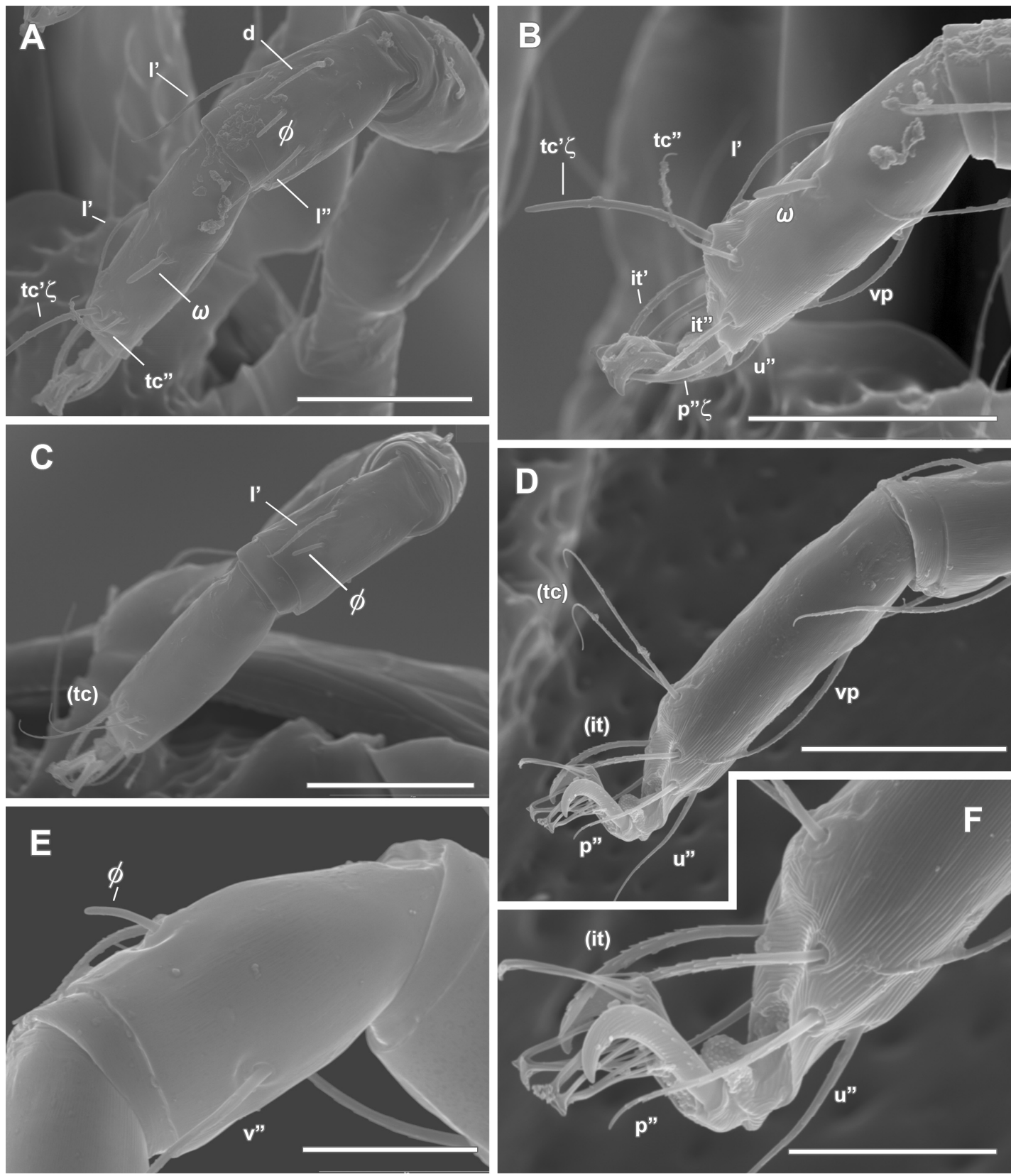

Fig. 12. Cryptognathus amalfitanii sp. nov., paratype (MACN-Ar 40666): A. dorsal view of the left tibia and tarsus II; B. antiaxial view of the left tarsus II; C. dorsal view of the left tibia and tarsus III; D, F, antiaxial view of the left tarsus IV; $\mathbf{E}$ left tibia III, antiaxial view. Scale bars: A; B; C; D $20 \mu \mathrm{m} ; \mathbf{E} ; \mathbf{F} 10 \mu \mathrm{m}$.

Table 2: length of the leg segments of the male.

\begin{tabular}{cccccc}
\hline Leg|segment & Tr. & Fe. & Ge. & Ti. & Ta. \\
\hline I & $30-32$ & $44-48$ & $34-38$ & $30-34$ & $38-42$ \\
II & $22-28$ & $30-36$ & $22-28$ & $22-24$ & $32-34$ \\
III & $24-28$ & $26-34$ & $24-28$ & $24-26$ & 36 \\
IV & $26-32$ & $36-46$ & $29-38$ & $26-34$ & $38-42$ \\
\hline
\end{tabular}


Table 3: length of the segments of the legs of the deutonymph.

\begin{tabular}{cccccc}
\hline Leg|segment & Tr. & Fe. & Ge. & Ti. & Ta. \\
\hline I & $28-30$ & $34-40$ & $36-40$ & $32-34$ & $36-38$ \\
II & $20-26$ & $26-30$ & $24-28$ & $24-26$ & $26-28$ \\
III & $24-30$ & $20-32$ & $28-30$ & $24-26$ & $30-34$ \\
IV & $26-30$ & $30-36$ & $30-38$ & 30 & $30-38$ \\
\hline
\end{tabular}

except for the presence of enlarged solenidia on tarsus III and IV. Lengths of solenidia: $\boldsymbol{I} \sigma: 4, \boldsymbol{I I} \sigma$ : $3, \boldsymbol{I} \phi$ ’: $5, \boldsymbol{I} \phi ”: 11, \boldsymbol{I I} \phi: 6, \boldsymbol{I I I} \phi: 6, \boldsymbol{I} \omega: 14-15, \boldsymbol{I I} \omega:$ 11-16, III $\omega:$ : 14-16, IV $\omega:$ : 14-16.

Deutonymph $(\mathrm{n}=2)$

\section{Gnathosoma}

Chelicerae 72-79; movable digits 28. Palpal setae as in adults; femur 29-32; genu 24-27 long; tibia 17-22 long, palptibial claw present; tarsus 8 long. Subcapitular setae $\boldsymbol{m}: 20-24, \boldsymbol{m}-\boldsymbol{m}$ : $12-20$; or 1 : 8, or2: 8 .

\section{Idiosoma}

Idiosoma 259-289 long, 146-154 wide al level of coxae IV, prodorsal projection small, not hoodlike; dorsal shield smooth, without the reticulations or pores presents in the adults; ventral shield finally striated; without genital valves or setae. Eyes 5-7 in diameter; pob 8-12 in diameter. Length of dorsal setae: vi: $7-13$; ve: $13-16$; sci: 16 ; c1: 16; sce: 13-20; d1: 16; e1: 13-18; e2: 14-19; f1: 12-17; h1: 14; h2: 16. Distance between dorsal setae: vi-vi: 18-19; vi-ve: 9 ; ve-ve: 30; ve-sci: 10; sci-sci: $30-46$; c1-c1: $53-55$; scesce: 102 ; c1-sce: 20-26; d1-d1: 64-76; d1-e1: 48-52; e1-e1: 40-46; e1-e2: 14-22; e2-e2: 70-76; e1-f1: 46-48; f1-f1: 50-55; f1-h1: 34-40; h1-h1: 13-16; h1-h2: 28-33; h2-h2: 70-75.

Legs For measurements see table 3. Counts of setae and solenidia on legs I-IV as in female. Lengths of solenidia: I $\sigma$ : 3-4, II $\sigma: 3-4, \boldsymbol{I} \phi^{\prime}$ : 4, I $\phi^{\prime}$ ': 10, II $\phi: 4-5$, III $\phi: 4, \boldsymbol{I} \omega: 10-11, \boldsymbol{I I} \omega:$ 7-8.

Remarks: The absence of solenidia on tarsus III and IV in immatures and females could indicate that it is the plesiomorphic condition for the genus.

\section{ACKNOWLEDGEMENTS}

Drs. Alireza Saboori (University of Tehran, Iran), Pablo A. Martinez (University of Mar del Plata, Argentina) and Andrés Ojanguren (Museo Argentino de Ciencias Naturales) made very valuable comments on the preliminary versions of the manuscript.

\section{REFERENCES}

Dŏgan, S. 2008. A catalogue of cryptognathid mites
(Acari: Prostigmata, Cryptognathidae) with the description of a new species of Favognathus Luxton and newly discovered male of $F$. amygdalus Dŏgan \& Ayyildiz from Turkey. Journal of Natural History 42: 1665-1686.

Dŏgan, S. \& G. Dönel. 2010. Cryptofavognathus, a new genus of the family Cryptognathidae Oudemans (Acari, Raphignathoidea) with the description of a new species from Turkey. Zootaxa 2533: 36-42.

Dönel, G. \& S. Dŏgan. 2011. A systematic investigation on cryptognathid mites (Acari: Cryptognathidae) of Kelkit Valley (Turkey). Türkiye Entomoloji Dergisi 35: 361-380.

Fan, Q. H. \& Z. Q. Zhang. 2005. Raphignathoidea (Acari: Prostigmata). Fauna of New Zealand 52: $1-400$.

Flechtmann, C. H. W. 1971. Alguns Trombidiformes do Brasil e do Paraguai (Acari). Livre Docência Thesis, not published, Escola Superior de Agricultura Luiz de Queiroz, Piracicaba (Brasil). 63 p.

Grandjean, F. 1944. Observations sur les acariens de la famille des Stigmaeidae. Archives des Sciences physiques et naturelles 26: 103-131.

Grandjean, F. 1946. Au sujet de l'organe de Claparède, des eupathides multiples et des taenidies mandibulaires chez les Acariens actinochitineux. Archives des Sciences physiques et naturelles 28: 63-87.

Khanjani, M. \& E. A. Ueckermann. 2008. New species of the genus Favognathus Luxton (Acari, Cryptognathidae) from Iran. Acarologia 48: 177-186.

Kethley, J. 1990. Acarina: Prostigmata (Actinedida). In: Dindal, D.L. (Ed.), Soil Biology Guide. John Wiley \& Sons, New York, pp. 667-756.

Luxton, M. 1973. Mites of the genus Cryptognathus from Australia, New Zealand and Niue Island. Acarologia, 15(1): 53-75.

Porta, A. \& F. Tricarico. 2018. Secado de muestras de ácaros de suelo para SEM usando HEXAMETHYLDISILAZANE (HDMS). Memorias del V congreso argentino de Microscopia SAMIC 2018. Available from: http://samic2018.congresos. unc.edu.ar/(last accessed 29 May 2019).

Robaux, P. 1975. Observations sur quelques Actinedida (= Prostigmates) du sol d'Amérique du nord. III. Description de deux nouvelles especes de Cryptognathus (Acari: Raphignathoidea-Cryptognathidae). Acarologia, 17(2): 257-269.

Summers, F.M. \& W.M. Chaudhri. 1965. New species of the genus Cryptognathus Kramer (Acarina: Cryptognathidae). Hilgardia, 36(7): 313-326.

Uluçay, I. \& K. Koç. 2013. Some cryptognathid mites (Acari: Cryptognathidae) from Kütahya Province (Turkey). Persian Journal of Acarology 2: 487-502.

Doi: 10.22179/REVMACN.21.640

Recibido: 12-V-2019 Aceptado: 26-X-2019 